\title{
Buccal Surface
}

National Cancer Institute

\section{Source}

National Cancer Institute. Buccal Surface. NCI Thesaurus. Code C52589.

The surface of the tooth facing or in direct contact with the oral mucosa of the cheek. 